\title{
Hubungan antara Kemiringan dan Posisis Lereng dengan Tekstur Tanah, Permeabilitas dan Erodibilitas Tanah pada Lahan Tegalan di Desa Gunungsari, Kecamatan Cikatomas, Kabupaten Tasikmalaya
}

\author{
Henly Yulina, Daud Siliwangi Saribun, dan Zulkarnaen \\ Adin \\ Jurusan Ilmu Tanah dan Sumber Daya Lahan, Fakultas \\ Pertanian, Universitas Padjadjaran, Jatinangor 40600 \\ Korespondensi: henlyyuliana2089@gmail.com
}

\author{
Muhammad Hilda Rizki Maulana \\ Alumni Jurusan Ilmu Tanah dan Sumber \\ Daya Lahan, Fakultas Pertanian, Universitas \\ Padjadjaran
}

\begin{abstract}
Relationship between slope and position of the slopes with soil texture, organic matter, soil permeability and erodibility on dry land in the Gunungsari Village, Cikatomas Sub District, Tasikmalaya District
\end{abstract}

Indonesia has a lot of potential lands especially for agricultural uses. In the areas with steep sloping topography and high human population, agricultural practices such as seasonal upland crops production becomes one of the issues in land damaging in Indonesia. This study aims were to determine the relationship between the land slope and the texture, organic matter, permeability and erodibility of soils at different slope positions in a land use so that can be used as a source of information and guidance to the community or the population around the village as well as the institutions involved in land management. The study used a free survey method based on toposekuen. The study techniques used comparative and descriptive methods to compare samples that collected in the conducted survey then performed explanation and description of the conditions in the field that qualitatively observed. The results showed that there was no significant relationship between the slope and the texture, organic matter, permeability and erodibility of soils in various slope positions. The $26-40 \%$ slopes in the middle and upper slope positions had the highest erodibility value compared to other slope and slope position.

Keywords: Slope, slope position, land use, erodibility, organic matter

\begin{abstract}
ABSTRAK
Indonesia memiliki banyak lahan yang sangat potensial khususnya di bidang pertanian. Pada daerah-daerah yang memiliki topografi berlereng curam dan berpenduduk padat, usaha pertanian seperti tanaman semusim tegalan merupakan salah satu sumber kerusakan tanah di Indonesia. Penelitian ini bertujuan untuk mengetahui hubungan antara kemiringan lereng dengan tekstur, bahan organik, permeabilitas dan erodibilitas tanah pada berbagai posisi lereng di suatu penggunaan lahan sehingga dapat dijadikan sebagai sumber informasi dan arahan bagi masyarakat atau penduduk di sekitar desa serta instansi yang terkait dalam pengolahan lahannya. Penelitian ini menggunakan metode survei bebas berdasarkan toposekuen. Teknik penelitian menggunakan metode komparatif dan deskriptif yaitu membandingkan sampel-sampel yang diambil berdasarkan metode survei yang dilakukan, kemudian menjelaskan dan menggambarkan kondisi di lapangan yang diamati secara kualitatif. Hasil penelitian menunjukkan bahwa tidak terdapat hubungan yang kuat antara kemiringan lereng terhadap tekstur tanah pada berbagai posisi lereng, kemiringan lereng terhadap bahan organik tanah pada berbagai posisi lereng, kemiringan lereng terhadap permeabilitas tanah pada berbagai posisi lereng serta antara kemiringan lereng terhadap erodibilitas tanah pada berbagai posisi lereng. Kemiringan lereng $26-40 \%$ pada posisi lereng tengah dan atas mempunyai nilai erodibilitas yang tertinggi dibandingkan dengan kemiringan dan posisi lereng lainnya.
\end{abstract}

Kata Kunci: Kemiringan, posisi lereng, penggunaan lahan, erodibilitas, bahan organik 


\section{PENDAHULUAN}

Indonesia merupakan salah satu negara yang secara geografis terletak pada garis khatulistiwa. Dilihat dari letak geografisnya sudah dapat dipastikan bahwa Indonesia memiliki banyak lahan yang sangat potensial untuk dikembangkan, khususnya di bidang pertanian (Rachman, 1988). Lahan kering merupakan salah satu sumberdaya lahan yang mempunyai potensi besar untuk pembangunan pertanian. Indonesia mempunyai aset nasional berupa pertanian lahan kering sekitar 121,4 juta hektar, atau sekitar 58,5\% dari luas seluruh dataran (Notohadiprawiro, 1989). Pemanfaatan lahan kering merupakan salah satu alternatif untuk memenuhi kebutuhan akan lahan pertanian yang terus meningkat akibat dari pembangunan dan pertambahan jumlah penduduk yang meningkat. Hal ini dilakukan karena potensi lahan kering cukup luas dimanfaatkan untuk budidaya tanaman.

Kondisi lahan tidak terlepas dari topografi. Kemiringan lereng dan panjang lereng adalah dua faktor yang menentukan karakteristik topografi suatu daerah (Asdak, 2002). Kedua faktor ini sangat penting dalam memengaruhi terjadinya erosi karena faktor-faktor tersebut menentukan besarnya kecepatan dan volume air larian. Kecepatan air larian yang besar umumnya ditentukan oleh kemiringan lereng, sedangkan kedudukan lereng menentukan besar-kecilnya erosi. Lereng bagian bawah lebih mudah tererosi daripada lereng bagian atas, karena momentum air larian lebih besar dan kecepatan air larian lebih terkonsentrasi ketika mencapai lereng bagian bawah.

Pada lereng atas akibat adanya tumbukan air hujan, menyebabkan hancurnya agregatagregat tanah. Partikel-partikel tanah yang terlepas diangkut oleh aliran permukaan menuruni lereng. Pada lereng yang lebih bawah, erosi yang terjadi akan lebih besar lagi karena disamping adanya pengaruh dari daya rusak butir hujan, juga dipengaruhi oleh aliran permukaan dari lereng bagian atas sehingga menyebabkan tanah yang terangkut lebih banyak. Bila kecepatan aliran permukaan berkurang, terjadilah pengendapan bahan. Pengendapan bahan ini bersifat sementara, dan biasanya terjadi pada lereng tengah. Kecepatan aliran permukaan yang tinggi menyebabkan kapasitas penghancuran semakin tinggi pula. Keadaan tersebut menunjukkan bahwa peristiwa erosi terjadi pada lereng atas, tengah dan bawah (Bermanakusumah, 1978). Selama terjadi aliran permukaan, air terkumpul di lereng bagian bawah dan akan terjadi pengendapan-pengendapan dari tanah yang tererosi. Hal tersebut menyebabkan lapisan permukaan tanah pada lereng bagian bawah menjadi lebih tebal (Kartasapoetra dkk., 1991) dengan demikian lereng bagian bawah akan memiliki sifat fisik dan kimia tanah yang lebih baik dibandingkan dengan lereng bagian atasnya.

Peranan tekstur tanah dalam memengaruhi erosi yaitu melalui pengaruhnya terhadap infiltrasi dan kapasitas menahan air (Hardjowigeno, 2003). Keadaan pori mikro dan makro juga memiliki peranan terhadap laju infiltrasi. Apabila keadaan tanah banyak memiliki pori mikro maka laju permeabilitas tanah akan semakin cepat dalam melewatkan air ke dalam tanah serta memperkecil aliran permukaan.

Pengaruh akibat terjadinya erosi menyebabkan terjadinya perubahan dan terganggunya sifat-sifat fisik dan kimia tanah. Apabila kejadian tersebut berlangsung secara terus-menerus maka dikhawatirkan daya tahan tanah terhadap erosi menjadi semakin berkurang.

\section{BAHAN DAN METODE}

Penelitian dilaksanakan di desa Gunungsari, Kecamatan Cikatomas, Kabupaten Tasikmalaya. Penelitian dilaksanakan pada bulan November 2010 hingga Februari 2011.

\section{Rancangan Penelitian}

Penelitian dilakukan dengan metode survei bebas berdasarkan toposekuen. Pengamatan, pengukuran dan pencatatan di lapangan dilakukan pada titik sampel yang ditentukan secara stratified purposing sampling, yaitu strata yang seragam dalam satuan peta lahan (SPL) hasil overlay peta lithologi, curah hujan, penggunaan lahan dan kemiringan lereng. Pengamatan meliputi pengukuran tekstur, permeabilitas, bahan organik dan erodibilitas tanah. Teknik penelitian menggunakan metode komparatif dan deskriptif yaitu membandingkan sampel-sampel yang diambil berdasarkan metode survei yang dilakukan, kemudian menjelaskan dan menggambarkan kondisi yang di lapangan yang diamati secara kualitatif. 


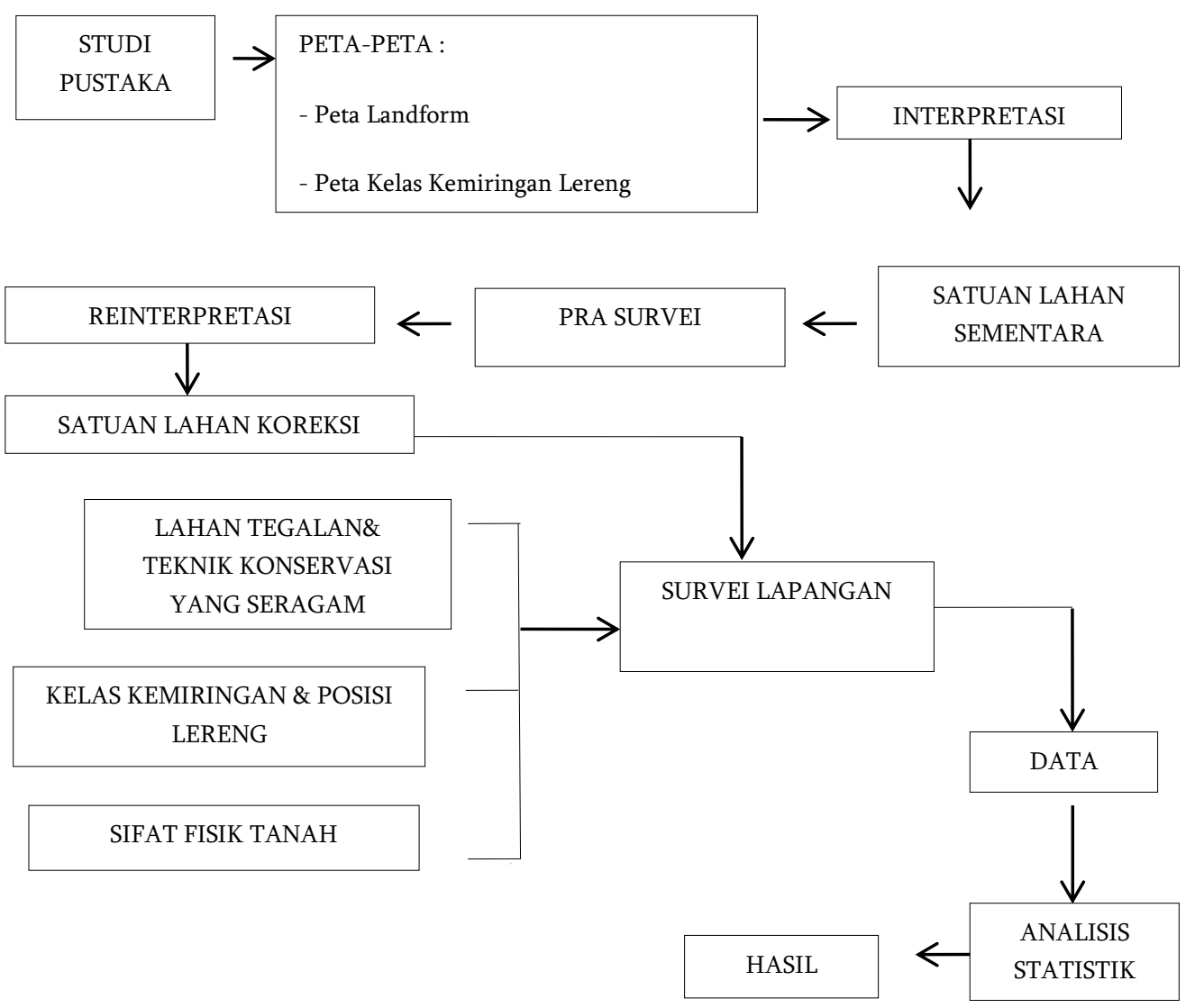

Gambar 1. Bagan alur penelitian.

Jumlah pengamatan sebanyak 27 titik dan dilakukan pada 3 kelas lereng. Masing-masing kelas lereng terdiri dari 3 posisi lereng, yaitu lereng atas, lereng tengah, dan lereng bawah. Kemudian ketiga posisi lereng tersebut diambil ulangan sebanyak 3 kali. Klasifikasi suatu lereng berdasarkan posisinya terdapat lima satuan lereng, yaitu: puncak lereng (ridge crest), lereng atas (upper slope), lereng tengah (mid slope), lereng bawah (lower slope), dan kaki lereng (foot slope) (Wiradisastra dkk., 1999). Dalam mengklasifikasikan lereng seperti di atas diperlukan adanya kriteria pembagian yang jelas. Young (1972) telah mengusulkan tiga kriteria yang harus dipakai yaitu patahan lereng (break of slope), perubahan lereng (change of slope), dan pembalikan lereng (inflection). Bagan alur penelitian disajikan pada Gambar 1.

\section{HASIL DAN PEMBAHASAN}

\section{Hubungan antara Kemiringan Lereng dengan} Fraksi Liat pada Berbagai Posisi Lereng

Hubungan antara kemiringan lereng dengan fraksi liat pada posisi lereng atas memperlihatkan korelasi negatif $\left(\mathrm{r}=-0,66^{\circ}\right)$ dan pada posisi lereng bagian tengah $\mathrm{r}=\left(-0,75^{\circ}\right)$. Fraksi liat menunjukkan kecenderungan menurun menurut kemiringan lereng yaitu sebesar 58,2\% pada lereng $8-15 \%$ menjadi $62,1 \%$ pada lereng 16 25\% dan menjadi 39\% di lereng 25-40\% (Gambar 2). Pada lereng bawah, hubungan antara kemiringan lereng dengan fraksi liat menunjukkan korelasi positif $(r=0,04)$ dimana semakin tinggi kemiringan lereng maka semakin tinggi fraksi liat. Pada kemiringan lereng $16-25 \%$ terjadi peningkatan liat. Hal ini dapat terjadi dikarenakan pada kemiringan lereng tersebut.

Berdasarkan koefisien determinasi $\left(\mathrm{R}^{2}\right)$, hubungan antara kemiringan lereng dan tekstur tanah pada berbagai posisi lereng berkisar antara 0,001-0,563 (0-56\%) (Gambar 3). Hal ini menunjukkan bahwa terdapat faktor lain yang mempengaruhi perbedaan fraksi liat selain kemiringan lereng. Faktor tersebut diduga adalah curah hujan yang cukup tinggi yang dapat mempengaruhi besarnya penghanyutan dan pencucian liat. 


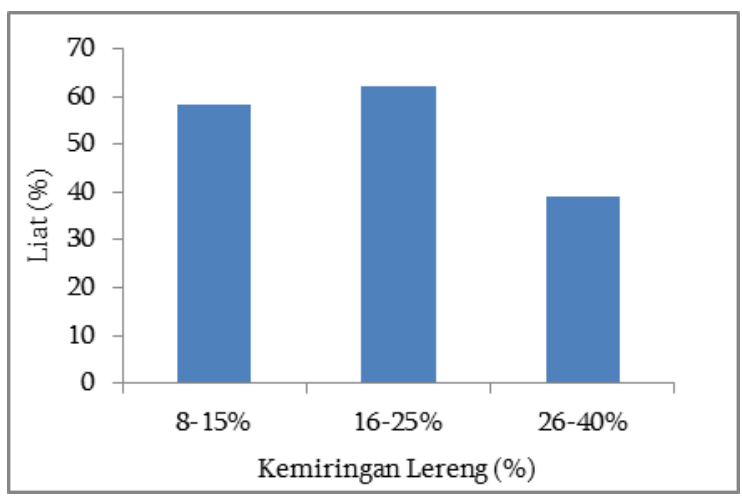

Gambar 2. Histogram kelas kemiringan lereng dengan rata-rata fraksi liat pada berbagai posisi lereng.

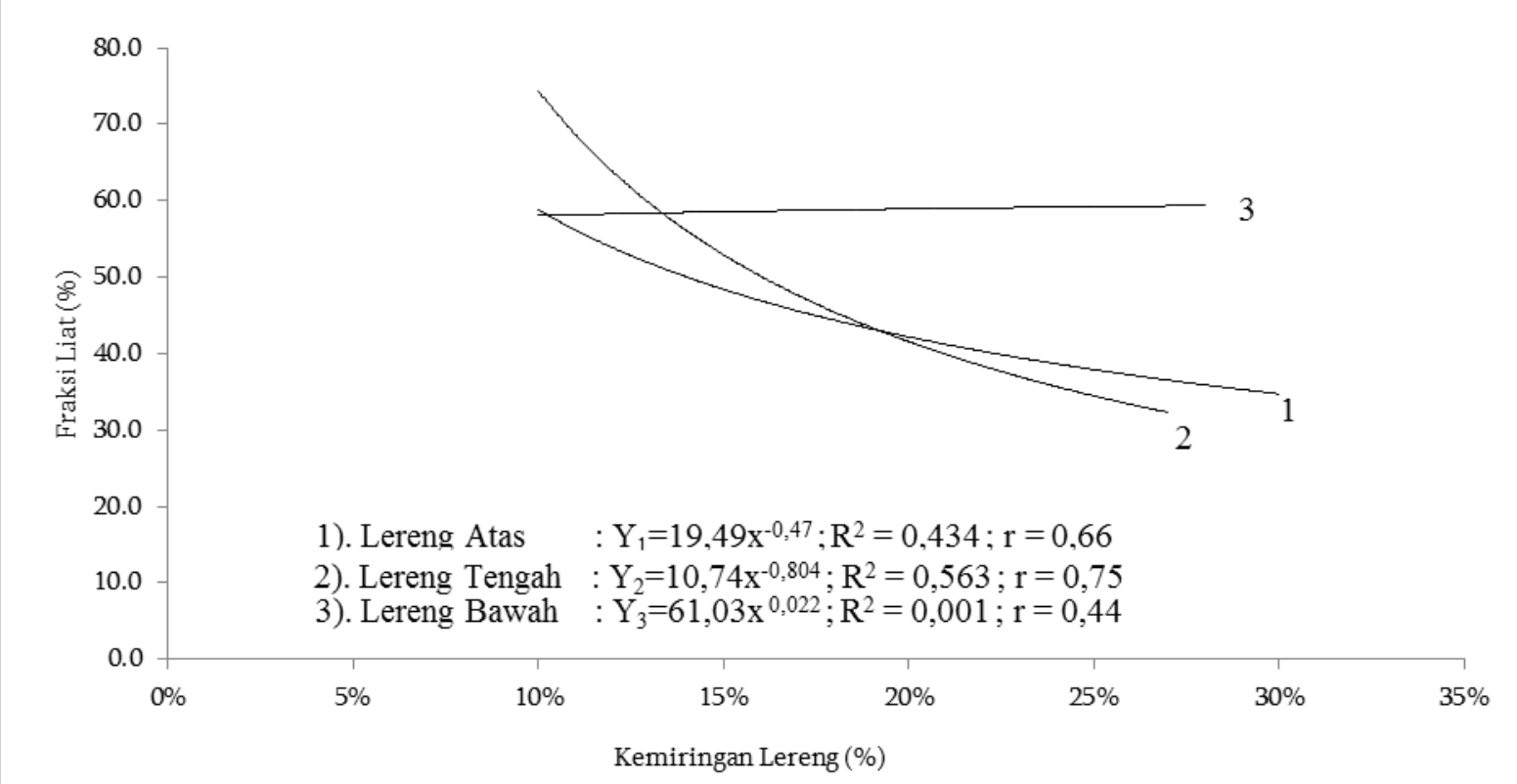

Gambar 3. Hubungan antara kemiringan lereng dengan fraksi liat pada berbagai posisi lereng.

Hubungan antara Kemiringan Lereng dengan Bahan Organik Tanah pada Berbagai Posisi Lereng

Berdasarkan hasil analisis statistik kandungan bahan organik tanah dengan kemiringan lereng pada posisi lereng bagian atas mempunyai nilai korelasi negatif $\left(r=-0,73^{*}\right)$, pada posisi lereng tengah $(\mathrm{r}=-0,58)$ dan pada posisi lereng bagian bawah $(r=-0,28)$. Bahan organik menunjukkan kecenderungan menurun seiring dengan meningkatnya kemiringan lereng yaitu $2,49 \%$ pada kemiringan lereng $8-15 \%$, menjadi $2,48 \%$ pada kemiringan lereng $16-25 \%$ dan menjadi $1,18 \%$ pada kemiringan lereng 26-40\% (Gambar 4). Menurut Arsyad (2000), dengan semakin curamnya lereng maka aliran permukaan akan semakin besar dimana tanah yang banyak mengandung bahan organik akan turut terangkut dan terbawa ke tempat yang lebih rendah.

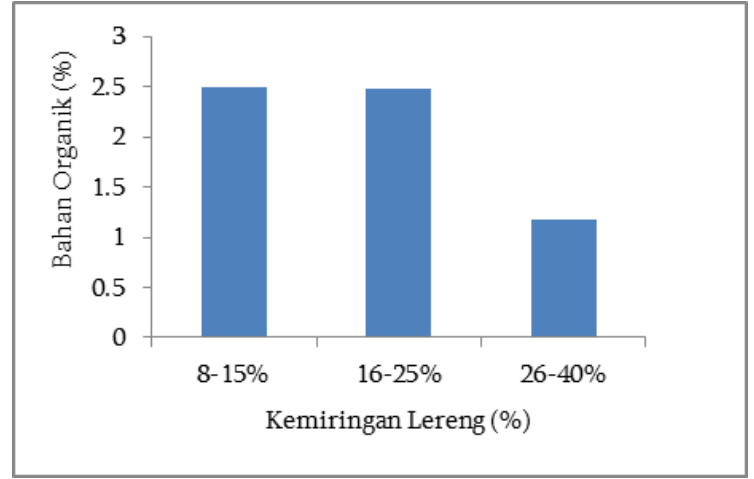

Gambar 4. Histogram kelas kemiringan lereng dengan rata-rata bahan organik pada berbagai posisi lereng. 
Berdasarkan koefisien determinasi $\left(\mathrm{R}^{2}\right)$, Hubungan kemiringan lereng dan C-organik tanah pada berbagai posisi lereng berkisar antara 0,07$0,536 \quad(0-53 \%) \quad$ (Gambar 5). Nilai koefisien determinasi yang sangat kecil menandakan pengaruh kemiringan lereng terhadap bahan organik kurang memuaskan. Hal ini diakibatkan ada faktor yang berpengaruh lebih besar terhadap kandungan bahan organik tanah, antara lain adalah vegetasi penutup tanah (ground cover). Serasah atau bagian tanaman yang sudah mati akan terdekomposisi dan meningkatkan kandungan bahan organik tanah.

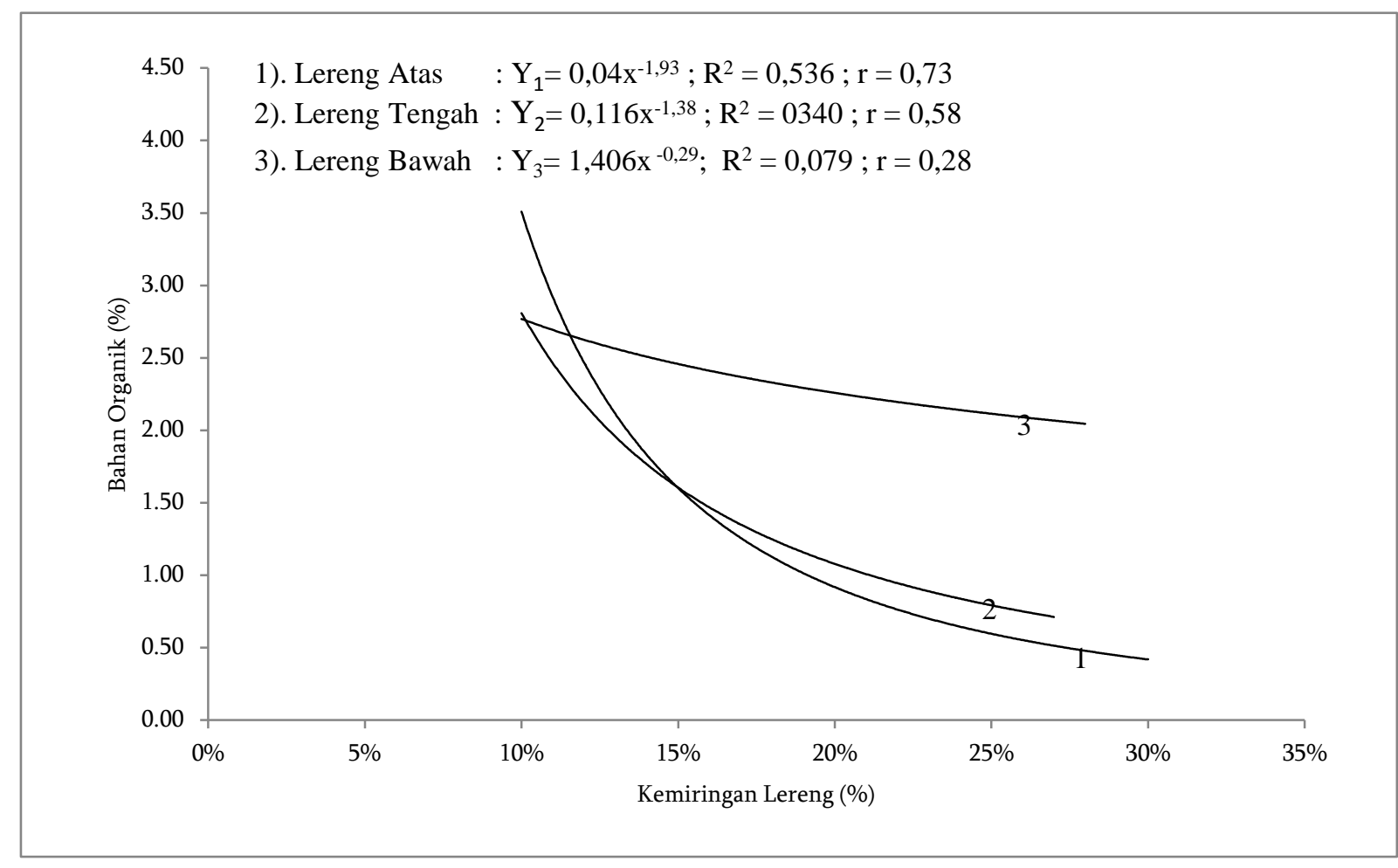

Gambar 5. Hubungan antara kemiringan lereng dengan bahan organik pada berbagai posisi lereng.

Hubungan antara Kemiringan Lereng dengan Permeabilitas Tanah pada Berbagai Posisi Lereng

Hubungan antara kemiringan lereng dengan permeabilitas tanah memperlihatkan adanya korelasi negatif $\left(r=-0,68^{*}\right)$ pada posisi lereng atas, pada posisi lereng bagian tengah $(\mathrm{r}=$ $0,17)$ dan pada posisi lereng bagian bawah $(\mathrm{r}=$ -0,43). Keadaan ini menunjukkan bahwa permeabilitas tanah mempunyai kecenderungan menjadi lebih lambat dengan semakin curamnya kemiringan lereng. Pada kemiringan lereng 8-15\% besar permeabilitas tanah sebesar $2,62 \mathrm{~cm} / \mathrm{jam}$, menjadi 3,60 cm/jam pada kemiringan lereng 16$25 \%$ dan menjadi $1,65 \mathrm{~cm} / \mathrm{jam}$ pada kemiringan lereng 26-40\% (Gambar 6). Laju permeabilitas pada kemiringan $16-25 \%$ terjadi peningkatan. Hal ini dikarenakan pada kemiringan lereng tersebut terjadi proses deposisi sementara.

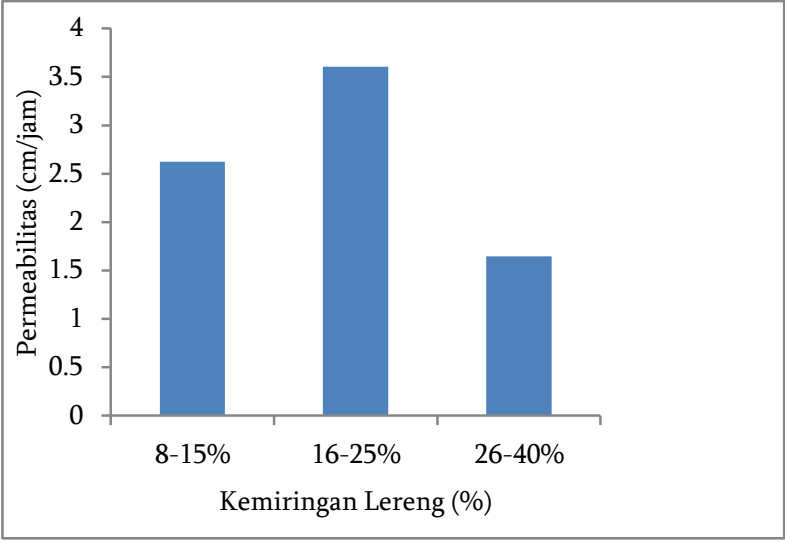

Gambar 6. Histogram kelas kemiringan lereng dengan rata-rata permeabilitas pada berbagai posisi lereng. 
Berdasarkan koefisien determinasi $\left(\mathrm{R}^{2}\right)$, hubungan antara kemiringan lereng dengan permeabilitas tanah pada berbagai posisi lereng berkisar antara 0,17-0,67 (17-67\%) (Gambar 7). Hal ini menunjukkan bahwa terdapat faktor lain yang memengaruhi perbedaan laju permeabilitas tanah selain kemiringan dan posisi lereng. Faktor tersebut diduga adalah bahan organik yang cukup tinggi yang dapat mempengaruhi besarnya pori makro sehingga akan meningkatkan laju permeabilitas tanah.

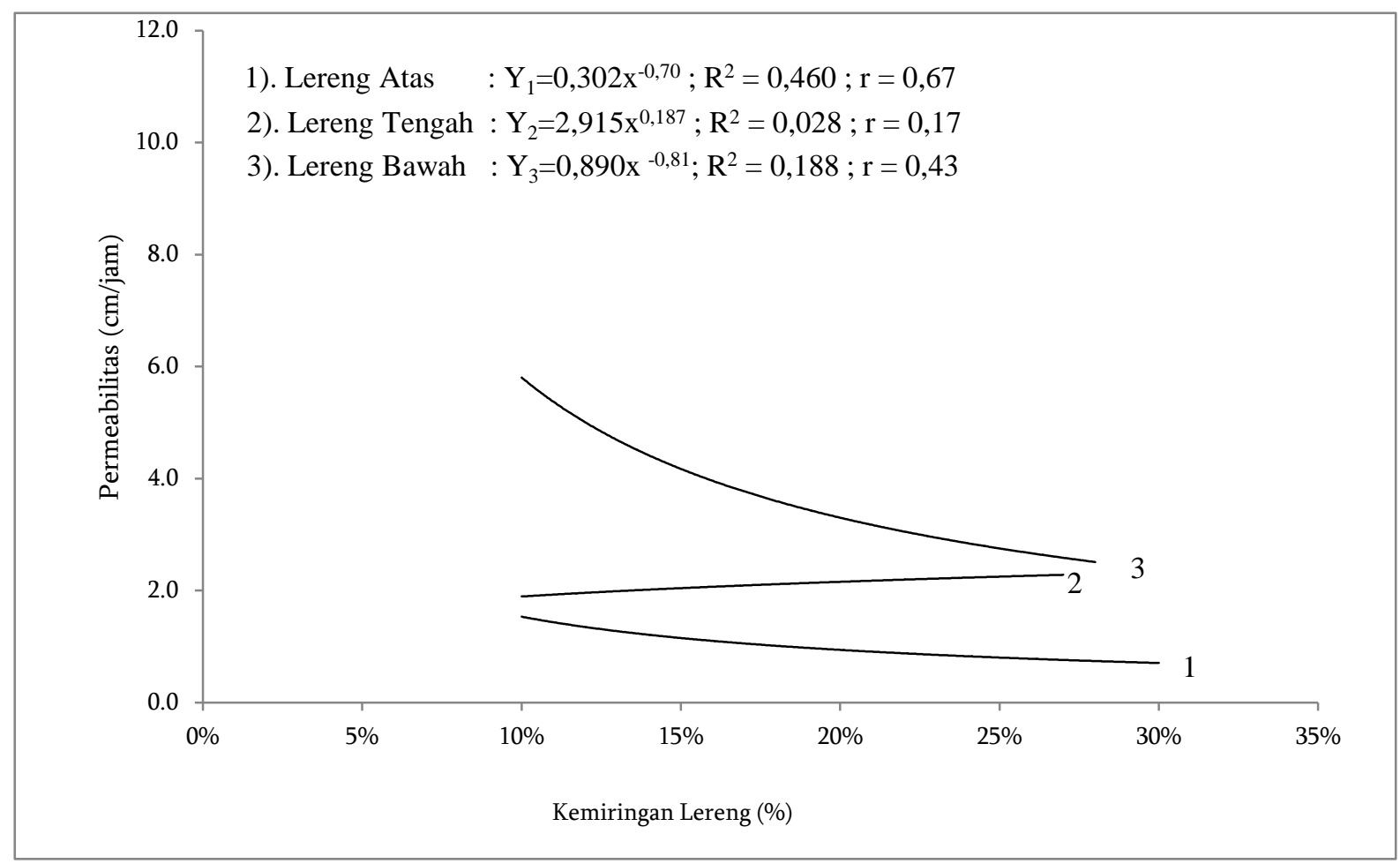

Gambar 7. Hubungan antara kemiringan lereng terhadap permeabilitas tanah pada berbagai posisi lereng.

\section{Hubungan antara Kemiringan Lereng dengan Erodibilitas Tanah pada Berbagai Posisi Lereng}

Hubungan antara kemiringan lereng dengan erodibilitas tanah memperlihatkan korelasi positif $\left(r=0,67^{*}\right)$ pada posisi lereng atas dan tengah. Hal ini menunjukkan bahwa semakin curamnya kemiringan lereng maka erodibilitas tanah akan semakin tinggi, maka tanah tersebut akan semakin tidak tahan terhadap erosi. Nilai erodibilitas tanah pada kemiringan lereng 8-15\% sebesar 0,20. menjadi 0,17 pada kemiringan lereng $16-25 \%$ dan menjadi 0,29 pada kemiringan lereng 26-40\% (Gambar 8). Pada kemiringan lereng 16$25 \%$ terlihat penurunan nilai erodibilitas tanah, hal ini dikarenakan pada kemiringan tersebut terjadi deposisi sementara yang mengakibatkan tanah tersebut menjadi lebih tahan terhadap erosi.

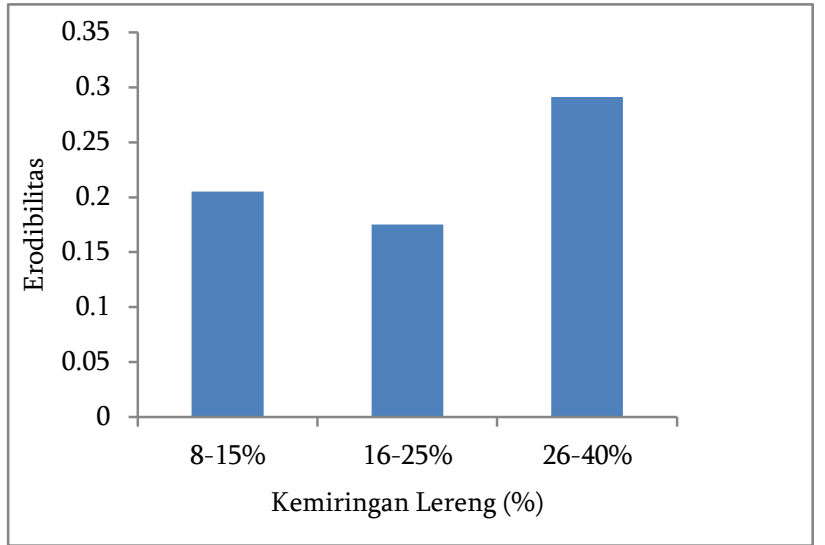

Gambar 8. Histogram kelas kemiringan lereng dengan rata-rata erodibilitas tanah pada berbagai posisi lereng. 
Hubungan antara fraksi liat dengan erodibilitas menunjukkan korelasi negatif $\left(\mathrm{r}=-0,96^{\circ}\right)$ pada posisi lereng atas, pada posisi lereng bagian tengah $\left(\mathrm{r}=-0,88^{*}\right)$ dan pada posisi lereng bagian bawah( $\mathrm{r}$ $\left.=-0,77^{*}\right)$ (Gambar 9). Hal ini menunjukkan bahwa semakin tingginya fraksi liat, maka akan semakin rendah nilai dari erodibilitas tanah. Penumpukan liat di daerah deposisi pada posisi lereng bawah menyebabkan tanah tersebut lebih tahan terhadap erosi. Sementara hilangnya liat di posisi lereng bagian atas merupakan suatu bukti tanah tersebut tidak tahan terhadap erosi sehingga akan meningkatkan nilai erodibilitas tanah.

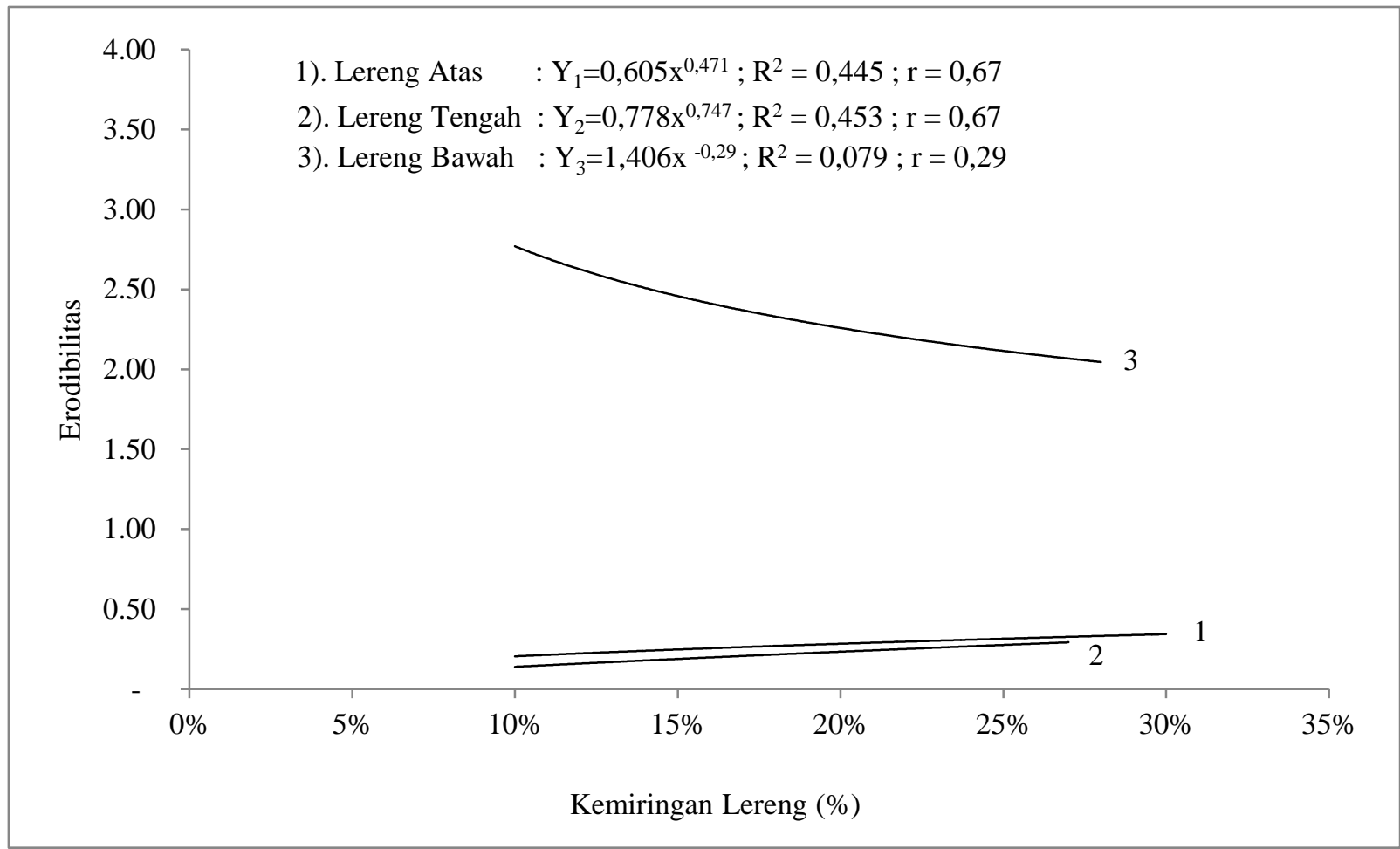

Gambar 9. Hubungan antara kemiringan lereng dengan erodibilitas tanah pada berbagai posisi lereng.

\section{SIMPULAN DAN SARAN}

Tidak terdapat hubungan yang kuat antara kemiringan lereng terhadap tekstur tanah pada berbagai posisi lereng $\left(\mathrm{r}=0,75^{*}\right)$, kemiringan lereng terhadap bahan organik tanah pada berbagai posisi lereng $\left(r=0,73^{*}\right)$, kemiringan lereng terhadap permeabilitas tanah pada berbagai posisi lereng $\left(r=0,67^{*}\right)$, serta antara kemiringan lereng terhadap erodibilitas tanah pada berbagai posisi lereng $\left(r=0,67^{*}\right)$. Kemiringan lereng 26$40 \%$ pada posisi lereng tengah dan atas mempunyai nilai erodibilitas yang tertinggi dibandingkan dengan kemiringan dan posisi lereng lainnya.

Nilai erodibilitas tanah pada wilayah yang diteliti termasuk ke dalam kelas tinggi. Diharapkan adanya penggunaan teknik konservasi, pengelolaan tanah, dan tanaman yang sesuai, agar lebih meningkatkan ketahanan tanah terhadap erosi.

\section{UCAPAN TERIMA KASIH}

Kami mengucapkan terima kasih kepada Bapak Kepala Desa Gunungsari, Kecamatan Cikatomas, Kabupaten Tasikmalaya atas izin menggunakan lahan untuk penelitian.

\section{DAFTAR PUSTAKA}

Arsyad, S. 2000. Konservasi Tanah dan Air. Institut Pertanian Bogor Press. Bogor.

Asdak, C. 2002. Hidrologi dan Pengelolaan Daerah Aliran Sungai. Gajah Mada University Press. Yogyakarta.

Bermanakusumah, R. 1978. Erosi, Penyebab dan Pengendaliannya. Fakultas Pertanian, Universitas Padjadjaran, Bandung.

Hardjowigeno, S. 2003. Klasifikasi Tanah dan Pedogenesis. Akademika Pressindo. Jakarta. 
Kartasapoerta, G, AG Kartasapoetra dan MM Sutedjo 1991. Teknologi Konservasi Tanah dan Air. Rineka Cipta. Jakarta.

Notohadiprawiro, T. 1989. Farming acid mineral soils for food crops: An Indonesian experience in Management of Acid Soils in the Humid Tropics of Asia. (ET Craswell and E Pushparajah, Eds.). ACIAR Monograph 1: 62-67.

Rachman, A. 1988. Efisiensi Teras Bangku dan Teras Gulud dalam Pengendalian Erosi. Risalah Diskusi Ilmiah Hasil Penelitian, Semarang.
Wiradisastra, US, B Tjahjono, K Gandasasmita, B Barus dan K Munibah. 1999. Geomorfologi dan Analisis Landskap. Laboratorium Penginderaan Jauh dan Kartografi, Jurusan Tanah, Fakultas Pertanian, Institut Pertanian Bogor, Bogor.

Young, A. 1972. Slopes. Longmas Groups Ltd. London. 